\title{
ANALYSIS OF THREE-DIMENSIONAL FLUORESCENCE SPECTRUM CHARACTERISTICS OF WATER EXTRACTABLE ORGANIC MATTER IN MOLLISOLS AFTER DIFFERENT YEARS OF CULTIVATION
}

\author{
WANG, T. Y. ${ }^{1,2 \#}-$ ZHAO, X. Y. ${ }^{1,2 \#}-$ WANG, C. Y. ${ }^{1,2}-$ HUANG, Z. Y. ${ }^{1,2}-$ LIU, S. X. ${ }^{1,2 *}$ \\ ${ }^{I}$ College of Resources and Environmental Science, Jilin Agricultural University, Changchun \\ 130118, Jilin Province, China
}

${ }^{2}$ Key Laboratory of Soil Resource Sustainable Utilization for Jilin Province Commodity Grain Bases, Changchun 130118, Jilin Province, China

*Corresponding author

e-mail: liushuxia69@163.com

(Received $1^{\text {st }}$ Apr 2019; accepted $13^{\text {th }}$ Jun 2019)

\begin{abstract}
Three-dimensional fluorescence technology was applied to analyze the components and structures of the water extractable organic matter (WEOM) in the topsoil $(0-20 \mathrm{~cm})$ and a $20-40 \mathrm{~cm}$ depth of Mollisol of an uncultivated land or the land after of 5,20,50 and 100 years of reclamation, respectively. With the continuous reclamation, the content of the WEOM in the black soil has a tendency of decreasing at first but increasing subsequently. The WEOM reaches its maximum and minimum contents at $86.65 \mathrm{mg} / \mathrm{kg}$ and $47.81 \mathrm{mg} / \mathrm{kg}$. The fluorescence intensity of the area III was enhanced. After the reclamation of 100 years, the fluorescence intensity of the areas III and Vreached to the top values, suggesting the maximum contents of fulvic acid-like and humic acid-like organic matters. The emitting lights at the fluorescence peak of the fluorescence area of humic acid-like organic matters also show red shift, indicating the increase of molecular weight, aromaticity and degree of polycondensation. However, the area IV remained unchanged. The research results showed that: with the reclamation, the components and structure, and the variation of WEOM in soil varies are related to the years of reclamation; the molecular weights, aromaticity and degrees of polycondensation in the WEOM increase evidently with the reclamation.
\end{abstract}

Keywords: dissolved organic carbon, fluorescence technology, substance composition, planting years, upland field soil

\section{Introduction}

The water extractable organic matter (WEOM) refers to organic matters dissolved in the soil solution or in the soil solution and a certain proportion of pure water after shaking extraction of organic compounds (Jones and Willett, 2006), and which can pass through the filter membrane of $0.45 \mu \mathrm{m}$ (Hassouna et al., 2010). It has a tiniest ratio in the total organic carbon of the soil, but gets involved in all kinds of biologic or abiologic processes, such as pedogenesis, carbon distribution and fixation, and environment behaviors of nutrient substances and pollutants in soil, therefore being of important significance (Landgraf et al., 2006). Generally, it is considered that the WEOM mainly comes from the root exudate of the land plants, the hydrolysate of fallen leaves and soil organic matters (McGill et al., 1981), and the metabolites of microorganism (Christ et al., 1996), and is composed of carbon hydrates, long-chain aliphatic compounds and proteins (Hassouna et al., 2010), in which the humic acid and fulvic acid account for about 25\%-50\%, and the others primarily are proteins, polysaccharides and hydrophilic organic acid (Weishaar et al., 2003). The content, 
components and structure of WEOM have been tested influenced by plant types, soil utilization methods, fertilization management, etc. The chemical composition of litter, varying with the plant types, obviously affects the existence of WEOM (Chantigny, 2003). For example, the WEOM has different and orderly reduced contents in the forest, grassland and plough (Wang et al., 2016). The fertilization, such as applying organic fertilizer and chemical fertilizer, shall change the content and structure of WEOM in soil (Liang et al., 2012). As for the soil utilization, after the natural land is reclaimed and turned into farmland, the content of WEOM is obviously reduced. The reclamation of land is regarded as the main reason for the reduction of WEOM (Graham et al., 2012). In terms of the distinctive fluorescence groups in the matters of WEOM, it is possible to analyze the WEOM by the fluorescence characteristics. Li et al. (2013) has researched the components and structure of WEOM in the soil of a farmland with a high maize outcrop by the fluorescence spectrum method, and indicated that the long-term application of nitrogen fertilizer shall affect the composition and structure of WEOM in the black soil, and further there is a parallelism between effect characteristics and application methods.

With fertile soil, the black soil area in the northeast of China ranks among the three largest black soil areas in the world, an extensive part of which has been reclaimed since one hundred years ago and been developed into the main commodity grain base of China with a high production level. Because of the reclamation of black soil, the soil fertility condition changed drastically, showing natural fertility reducing gradually (Provenzano et al., 2004). To a large extent, the natural fertility of soil depends on the quantity and quality of organic carbon in soil. As WEOM is the main part of the active organic carbon pool of soil, it can indicate the variation of quantity and quality of organic matters in soil (Liang et al., 2011). Therefore, this work, in virtue of the 3D fluorescence spectrum technology, has studied the content, composition, and structure of WEOM in the black soil after different years of reclamation, thereby providing a theory basis for deepening the recognition of reclamation's effects on the organic matters and quality of soil to increase the carbon fixation of black soil and improve the soil quality.

\section{Materials and methods}

Soil samples were collected in a Mollisol located in Haiqing village, Guojia county, Dehui city, Jilin province situated in the upper part of the corn belt region in China (N44³0'35.41" E125³3'20.90"). Sampling was performed at two depths, topsoil (0$20 \mathrm{~cm}$ ) and 20-40 cm depth. Samples were taken in five adjacent soil plots of the uncultivated land and the cultivated land after the years of reclamation of 5, 20, 50 and 100 , respectively. The soil was planted with maize and was ploughed each spring. With the snake-pattern five-point sampling method, the sampling is conducted in the sites with similar topography conditions and having shortest distance in between to minimize the topography disturbance. The basic physical and chemical properties of the tested soil are listed in Table 1. 
Table 1. Basic physicochemical properties of tested samples

\begin{tabular}{c|c|c|c|c|c|c|c|c}
\hline $\begin{array}{c}\text { Depth } \\
(\mathbf{c m})\end{array}$ & Years & $\begin{array}{c}\mathbf{W}-\mathbf{C} \\
(\mathbf{\%})\end{array}$ & $\mathbf{p H}$ & $\begin{array}{c}\mathbf{V}-\mathbf{W} \\
(\mathbf{g} / \mathbf{c m 3})\end{array}$ & $\begin{array}{c}\mathbf{A}-\mathbf{P} \\
(\mathbf{m g k g} /)\end{array}$ & $\begin{array}{c}\mathbf{A}-\mathbf{K} \\
(\mathbf{m g} / \mathbf{k g})\end{array}$ & $\begin{array}{c}\mathbf{A}-\mathbf{N} \\
(\mathbf{m g} / \mathbf{k g})\end{array}$ & $\begin{array}{c}\mathbf{T}-\mathbf{N} \\
(\mathbf{g} / \mathbf{k g})\end{array}$ \\
\hline \multirow{5}{*}{$0-20$} & 0 & $4.68 \pm 0.10$ & $7.63 \pm 0.14$ & $1.06 \pm 0.02$ & $30.54 \pm 1.21$ & $283.12 \pm 3.83$ & $174.12 \pm 2.22$ & $2.25 \pm 0.03$ \\
& 5 & $3.71 \pm 0.17$ & $7.85 \pm 0.05$ & $1.01 \pm 0.03$ & $22.06 \pm 1.34$ & $185.22 \pm 4.13$ & $86.34 \pm 2.34$ & $1.74 \pm 0.02$ \\
& 20 & $4.29 \pm 0.21$ & $8.04 \pm 0.07$ & $1.09 \pm 0.05$ & $14.38 \pm 1.98$ & $156.34 \pm 3.12$ & $76.45 \pm 3.02$ & $1.59 \pm 0.09$ \\
& 50 & $5.02 \pm 0.29$ & $7.35 \pm 0.12$ & $1.07 \pm 0.08$ & $19.72 \pm 1.89$ & $200.67 \pm 4.23$ & $90.98 \pm 3.19$ & $1.85 \pm 0.10$ \\
& 100 & $5.07 \pm 0.32$ & $8.13 \pm 0.09$ & $1.32 \pm 0.02$ & $3.64 \pm 2.11$ & $135.98 \pm 2.99$ & $82.65 \pm 2.18$ & $1.72 \pm 0.11$ \\
\hline \multirow{4}{*}{$20-40$} & 0 & $4.68 \pm 0.14$ & $7.63 \pm 0.03$ & $1.06 \pm 0.09$ & $6.16 \pm 2.45$ & $180.76 \pm 4.21$ & $77.55 \pm 2.98$ & $1.82 \pm 0.12$ \\
& 5 & $3.93 \pm 0.09$ & $8.37 \pm 0.11$ & $1.31 \pm 0.05$ & $2.42 \pm 1.77$ & $59.33 \pm 3.08$ & $61.20 \pm 1.34$ & $1.47 \pm 0.06$ \\
& 20 & $6.31 \pm 0.15$ & $8.04 \pm 0.08$ & $1.12 \pm 0.10$ & $3.95 \pm 1.20$ & $60.21 \pm 4.70$ & $74.43 \pm 1.98$ & $1.71 \pm 0.01$ \\
& 50 & $4.59 \pm 0.26$ & $7.64 \pm 0.16$ & $1.32 \pm 0.11$ & $7.91 \pm 1.34$ & $138.55 \pm 3.17$ & $84.78 \pm 2.31$ & $1.78 \pm 0.12$ \\
& 100 & $5.07 \pm 0.13$ & $8.13 \pm 0.15$ & $1.32 \pm 0.07$ & $2.55 \pm 1.21$ & $55.79 \pm 1.99$ & $36.67 \pm 2.17$ & $0.75 \pm 0.03$ \\
\hline
\end{tabular}

W-C: Water content; V-W: Volume weight; A-P: Available phosphorus; A-K: Available potassium; A$\mathrm{N}$ : Available nitrogen; T-N: Total nitrogen

\section{Extraction and determination of the water extractable organic matter}

WEOM extract by the steam water. The soil of $25 \mathrm{~g}$ in dry weight, having passed through the $2 \mathrm{~mm}$-grade sieve, were put into the triangular flask, and added with the distilled water of $100 \mathrm{ml}$. The mixture in the flask then was vibrated under the normal temperature for $30 \mathrm{~min}$, and centrifuged by a high-speed centrifugal machine of $8000 \mathrm{rpm}$ for $5 \mathrm{~min}$. After stabilizing for another $5 \mathrm{~min}$, the supernatant was separated from the mixture, and filtrated by the $0.45 \mu \mathrm{m}$-grade filter membrane. The collected filtrate was just WEOM, which was used to test the content and analyze the threedimensional fluorescence spectrum of WEOM. And the concentration of organic carbon in filtrate was measured by the Shimadzu TOC-VCPH analyzer (Li et al., 2013).

\section{Test method}

The HATACH F-7000-type fluorescence spectrophotometer produced by Hitachi was used for the fluorescence spectrum analysis of WEOM, with the xenon lamp as the light source of $150 \mathrm{~W}$, the voltage of photomultiplier of $700 \mathrm{~V}$, the silt widths for excitation and emitting lights of $5 \mathrm{~nm}$, the wave length of 220-420 $\mathrm{nm}$ and the wavelength interval of $5 \mathrm{~nm}$ for excitation lights, and those separately of 280-560 nm and $1 \mathrm{~nm}$ for emitting lights (Li et al., 2013), as shown in Figure 1.

Determination of basic physicochemical properties of soil were completed with the water content in soil tested by the oven drying method, the $\mathrm{pH}$ value by the $\mathrm{pH}$ meter, the volume weight by the cutting-ring method, the available phosphorus by the sodium bicarbonate extraction and molybdenum-blue colorimetry, the available potassium by the $\mathrm{NH}_{4} \mathrm{OAc}$ extraction and flame photometer, the available nitrogen by the alkaline hydrolysis diffusion method, the total nitrogen by the semimicro-kjeldahl determination, and the soil organic matter (SOM) by the potassium dichromate method with outside heating (Shi and Bao,1908).

\section{Data processing}

The data processing and analysis was conducted by virtue of Origin 7.5, SPSS19.0, Excel 2010, etc. 


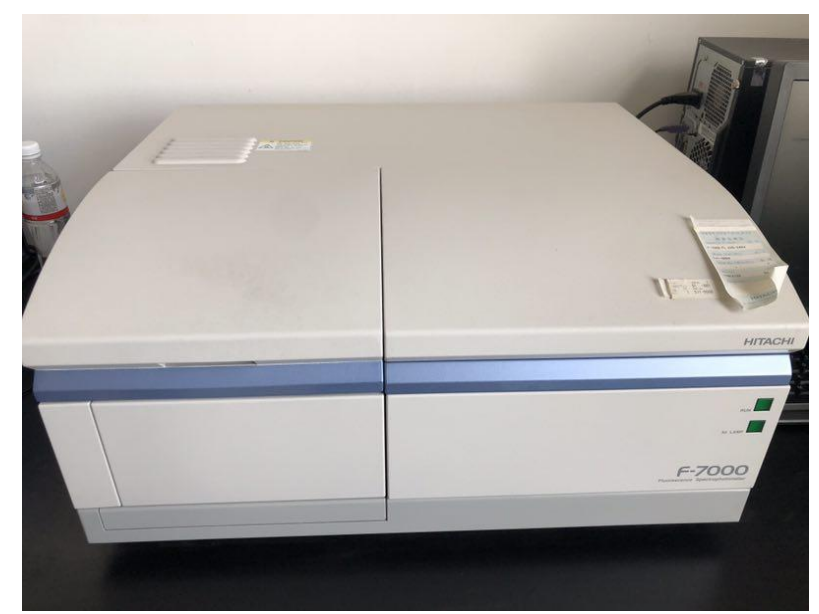

Figure 1. HATACH F-7000-type fluorescence spectrophotometer

\section{Results and discussion}

\section{Content of the water extractable organic matter in black soil after different years of reclamation}

The content of WEOM in black soil after years of reclamation was measured by the organic carbon analyzer (TOC), and the results are listed in Table 2. As indicated by the results, the cultivation had certain effects on the WEOM in black soil. In terms of the top soil (0-20 cm underground), the content of WEOM in black soil had a negative growth in the first few years and subsequently recovered to certain levels in the following years. The WEOM has the maximum and minimum contents, i.e. $86.65 \mathrm{mg} / \mathrm{kg}$ and $47.81 \mathrm{mg} / \mathrm{kg}$, separately in the uncultivated land and the black soil after 5 years of reclamation and is less abundant in the soil after reclamation of 100 years in comparison with the uncultivated land. However, in the plough $(20-40 \mathrm{~cm}$ underground), the black soil after 5 years of reclamation had the maximum ratio of WEOM, $124.99 \mathrm{mg} / \mathrm{kg}$, and this content decreased to the lowest of $61.55 \mathrm{mg} / \mathrm{kg}$ with the years up to 50. As for SOM, with reclamation, it is subject to a same variation of content both in the top soil and plough, and has been proven more prolific in the top soil comparatively. However, a certain relation of the content of SOM versus soil types has not been figured out.

Basically identical with the results obtained by Graham et al. (2012), one conclusion of this research is that the soil with zero or less human disturbances bears a high content of WEOM, but the content should plummet in the events of some strong disturbances. The obvious changes of WEOM with the exploitation of land indicate it is primarily the land reclamation that should be the reason of the reduction of WEOM in soil. With the natural soil reclaimed, a large drop of WEOM occurred in the soil, and the reduction continued, to the largest extent at the 50th year of reclamation. Subsequently, the reducing was reversed, and the content starts to grow in the succeeding years. We concluded that in order to solve the problems caused by the increasing reclamation and singular plant, more fertilizers should be applied, which prompt in different levels the organic carbons in bodies of animals and plants transforming to those in the soil.

The ratio of WEOM in the total organic matters has a same variation along with its content, which has a reduction of $17.1-44.8 \%$ in the cultivated land compared to the uncultivated land. The experiment analysis reveals the content of WEOM varies greatly 
in the black soil after different years of reclamation and indicates that the reclamation is the main factor influencing the WEOM content in the black soil.

Table 2. Variation of the water extractable organic matter contents with reclamation ( $a, b, c$, and $d$ are the grades of variation)

\begin{tabular}{c|c|c|c|c}
\hline $\begin{array}{c}\text { Depth } \\
(\mathbf{c m})\end{array}$ & Years & $\begin{array}{c}\text { SOM } \\
(\mathbf{g} / \mathbf{k g})\end{array}$ & $\begin{array}{c}\text { WEOM } \\
(\mathbf{m g} / \mathbf{k g})\end{array}$ & $\begin{array}{c}\text { WEOM/SOM } \\
(\mathbf{\%})\end{array}$ \\
\hline & 0 & $29.19 \mathrm{a}$ & $86.65 \mathrm{a}$ & 0.297 \\
$0-20$ & 5 & $29.27 \mathrm{a}$ & $75.84 \mathrm{~b}$ & 0.259 \\
& 20 & $25.46 \mathrm{~b}$ & $72.36 \mathrm{c}$ & 0.284 \\
& 50 & $25.43 \mathrm{~b}$ & $47.81 \mathrm{~d}$ & 0.188 \\
& 100 & $24.15 \mathrm{~b}$ & $71.79 \mathrm{c}$ & 0.294 \\
\hline \multirow{3}{*}{$20-40$} & 0 & $28.64 \mathrm{a}$ & $80.98 \mathrm{~b}$ & 0.283 \\
& 5 & $28.36 \mathrm{a}$ & $124.99 \mathrm{a}$ & 0.441 \\
& 20 & $21.41 \mathrm{~b}$ & $71.83 \mathrm{c}$ & 0.335 \\
& 50 & $23.63 \mathrm{~b}$ & $61.55 \mathrm{e}$ & 0.26 \\
\hline
\end{tabular}

SOM: the soil organic matter; WEOM: the water extractable organic matter

\section{Characteristics of three-dimensional fluorescence spectrum of the water extractable organic matter in black soils after different years of reclamation}

Figure 2 is a collection of three-dimensional fluorescence spectrograms of WEOM in soil after different years of reclamation, which reflects great differences between these fluorescence spectrograms. As reported by Chen et al. (2015), a spectrogram shall be divided into 5 sections based on the wavelengths of excitation and emitting lights, the I section representing the tyrosine acid-like protein (for which the wavelength is 220$250 \mathrm{~nm} / 280-330 \mathrm{~nm}$ ), the II section the tryptophan acid-like protein (the wavelength is $220-250 \mathrm{~nm} / 330-380 \mathrm{~nm}$ ), the III section the fulvic acid-like substances (the wavelength is $220-250 \mathrm{~nm} / 380-480 \mathrm{~nm}$ ), the IV section the soluble microbial metabolites acid-like substances (the wavelength is $250-360 \mathrm{~nm} / 280-380 \mathrm{~nm}$ ), and the V section the humic acid-like substances (the wavelength is $250-420 \mathrm{~nm} / 380-520 \mathrm{~nm}$ ), respectively.

Suggested by Figure 2, the shapes of spectrograms and intensities of fluorescence vary with the reclamation years. The WEOM in all soil types is composed of the tyrosine acid-like protein, tryptophan acid-like protein, fulvic acid-like substances, soluble microbial metabolites acid-like substances, and humic acid-like substances, especially the latter three types. Compared with the uncultivated land being taken as the control group, the cultivated land was shown with evidently intensified fluorescence of the III section, which means the more enrichment of fulvic acid-like substances. After the reclamation of 100 years, the III and V sections reach to the maximum fluorescence intensities, especially for the III section with an evident peak value. Furthermore, in contrast, it is the top soil rather than the plough with the higher fluorescence density, mainly for the fulvic and humic acid-like substances. The difference shall be explained by the continued addition of organic matters into the top soil from the straw stubble per year, which resulted in the growing percentage of organic matters as well as humic organic matters in soil; but the much less organic matters applied to the plough stimulate the relatively lower activity of microorganisms. 

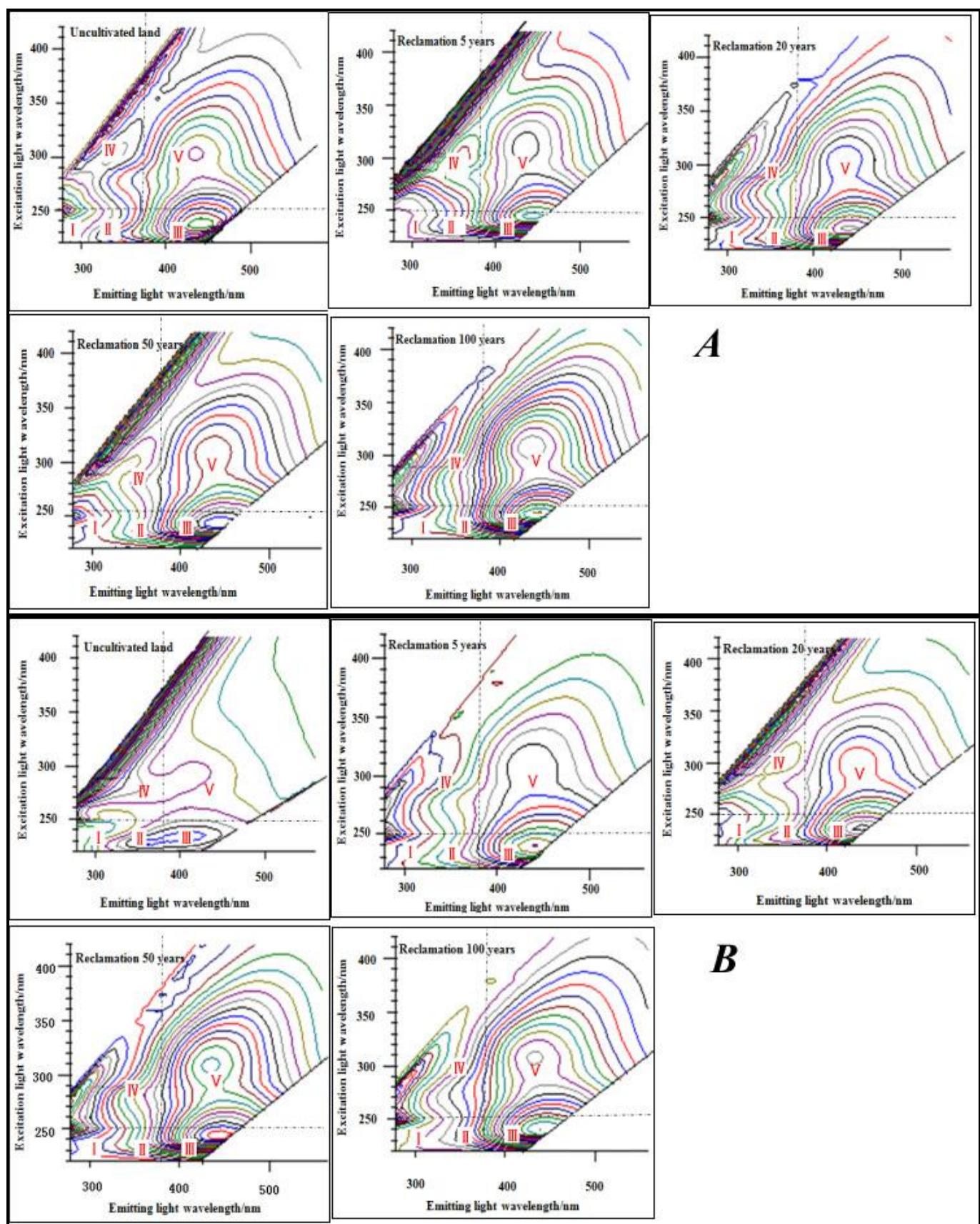

$\boldsymbol{B}$

Figure 2. The black soil of Fluorescence characteristics of the water extractable organic matter after different years of reclamation. (A: topsoil B: plough; the density of isoline represents the intensity of fluorescence I - tyrosine acid-like protein, II - tryptophan acid-like protein, III fulvic acid-like substances, IV - soluble microbial metabolites acid-like substances, $V$ - humic acid-like substances. The HATACH F-7000-type fluorescence spectrophotometer produced by

Hitachi was used for the fluorescence spectrum analysis, with the xenon lamp as the light source of $150 \mathrm{~W}$, the voltage of photomultiplier of $700 \mathrm{~V}$, the silt widths for excitation and emitting lights of $5 \mathrm{~nm}$ )

Basically identical with the results by Li et al. (2013), this research indicates the III and $\mathrm{V}$ sections have the most intensified fluorescence, which suggests the fulvic-acid and humic acid organic matters are most abundant in soil. With the fertilizer application 
for relieving the problems of reclamation, the fulvic-acid and humic acid organic matters accumulated in soil. The longer the reclamation continued, the more effects were on humic organic matters. It could be explained that with the reclamation, the accumulation of residues of plants gathered more microorganisms and produced a growing number of metabolites. Accordingly, the soil was substantially enriched by many types of fulvic acid and humic acid of complex structures and high aromaticity.

\section{Semi-quantitative analysis of fluorescent substances in black soil after different years of reclamation}

To compare the substance composition of black soil after different years of reclamation, the integral computation of fluorescence areas in Figure 2 has been finished, and the results are shown in Figure 3.
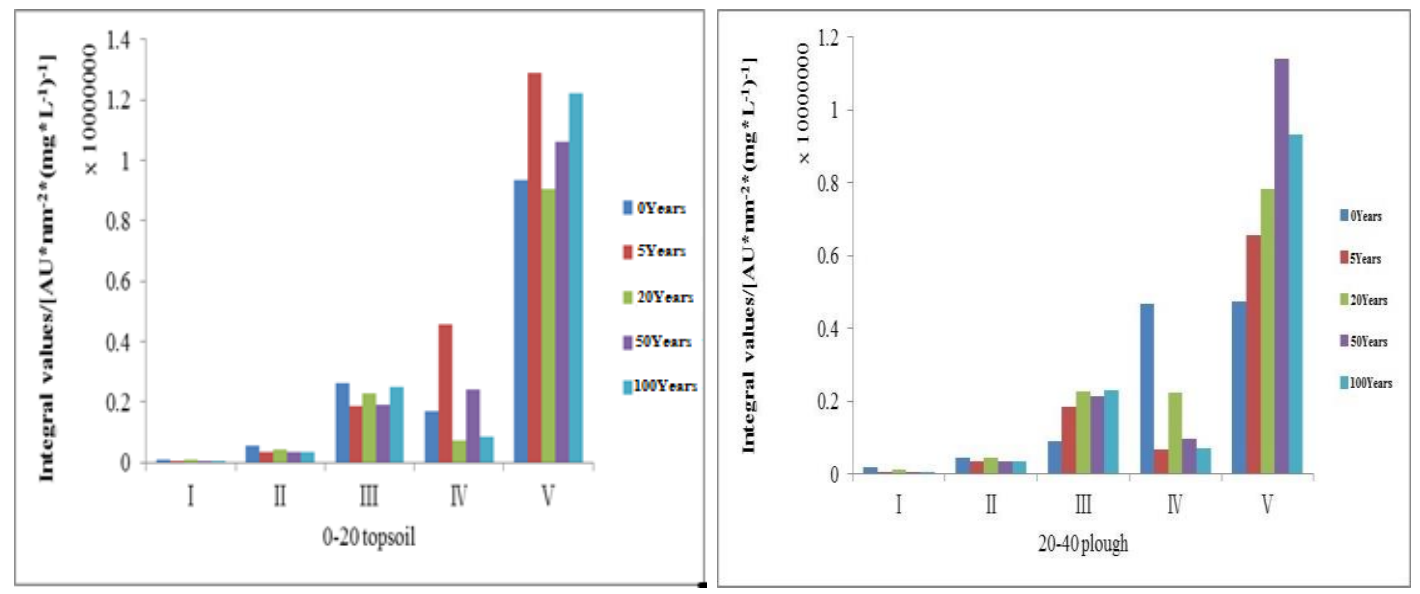

Figure 3. Integral characteristics of $I$ - V fluorescence areas of the water extractable organic matter after different years of reclamation. (0-20 underground for topsoil, 20-40 underground for plough by the origin)

Figure 3 indicates the integral values are ordered decreasingly as V, III, IV, II and I. As for the top soil, the integral for the fluorescence area of II descended from $5.4 \times 10^{5}$ $\mathrm{AU} \times \mathrm{nm}^{-2} \times\left(\mathrm{mg} \times \mathrm{L}^{-1}\right)^{-1}$ to $3.4 \times 10^{5} \mathrm{AU} \times \mathrm{nm}^{-2} \times\left(\mathrm{mg} \times \mathrm{L}^{-1}\right)^{-1}$, suggesting the less tryptophan acid-like protein in the WEOM; on the contrary, the more enrichment of humic acid-like substances is reflected by the increase of the integral for the fluorescence area of V from $9.3 \times 10^{6} \mathrm{AU} \times \mathrm{nm}^{-2} \times\left(\mathrm{mg} \times \mathrm{L}^{-1}\right)^{-1}$ to $12.2 \times 10^{6} \mathrm{AU} \times \mathrm{nm}^{-2} \times\left(\mathrm{mg} \times \mathrm{L}^{-1}\right)^{-1}$. This variation can be explained by the enhanced metabolic activities with reclamation, which utilized the water soluble tyrosine acid-like protein and tryptophan acid-like protein, and converted organic matters in soil to humic acid-like substances. However, the integral for the fluorescence area of III kept nearly stable, which is the sign of the stability of humic acid-like substances in content. As for the plough, it was also subject to the disturbance of reclamation, and the test results with the exception of the increasing content of humic acid are basically same with those in the top soil.

Figure 4 indicates the integral percentages of all sections. Conclusions can be drawn that the tyrosine acid-like protein and tryptophan acid-like protein represented by the I and II sections kept relatively lower integral percentages regardless of the years of reclamation; the percentage of fulvic-acid substances represented by the III section 
increases firstly until to the maximum value in the $20^{\text {th }}$ years, and reduced in the following years; the percentage of the $\mathrm{V}$ section tended to increase, indicating the rising content of fulvic-acid organic matters in soil; besides, the nearly stable percentage of the IV section reflected the stabilized content of soluble microbial metabolites.
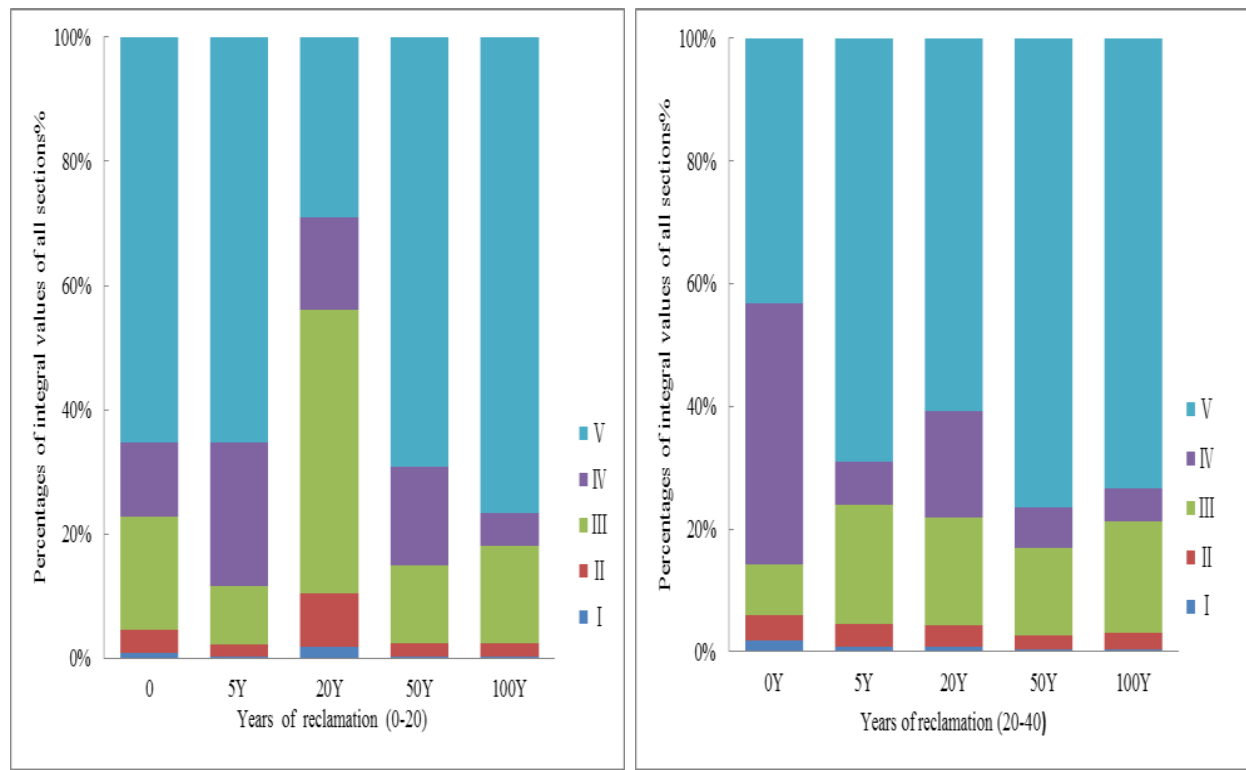

Figure 4. Percentages of integrals of all sections. (0-20 for topsoil, 20-40 for plough) by the origin

\section{Analysis of locations of fluorescence peaks and fluorescence intensity}

The fluorescence peaks and corresponding wavelengths of excitation and emitting lights for WEOM can characterize their structures and compositions. It is proved that the variation of molecule and aromaticity of a kind of fluorescence substance is reflected by the evolution of wavelengths of excitation and emitting lights at fluorescence peaks. If the wavelength lengthens (i.e. the lights have red shift), the aromaticity and molecule of fluorescence substance is considered increased; if the wavelength shortens (i.e. the lights have blue shift), the aromaticity and molecule of fluorescence substance is considered reduced ( $\mathrm{Fu}$ et al., 2004). As can be seen in Table 3, for the top soil, the I and II areas have red shifts of excitation lights from $225 \mathrm{~nm}$ to $240 \mathrm{~nm}$ and from $230 \mathrm{~nm}$ to $245 \mathrm{~nm}$, respectively. Such red shift suggests the obvious increase of molecules and aromaticity of tyrosine acid-like protein and tryptophan acid-like protein. Accordingly, more abundant proteins were generated in soil with reclamation. The emitting light of fulvic-acid substances at the peak has a red shift from $440 \mathrm{~nm}$ to $448 \mathrm{~nm}$, indicating the increases in molecule, aromaticity and the degree of polymerization.

The excitation and emitting lights of the IV area at the peaks have no variation, which reflects the stability of molecule and aromaticity of soluble microbial metabolites acid-like substances. While for the area III, the excitation and emitting lights have red shifts from $235 \mathrm{~nm}$ to $245 \mathrm{~nm}$ and from $440 \mathrm{~nm}$ to $447 \mathrm{~nm}$ respectively, which is the sign of increasing content, aromaticity and molecule of fulvic-acid substances in the WEOM. But in comparison with the top soil, the smaller changes of aromaticity and 
molecules in the plough shall be explained by the weak disturbance of reclamation to the plough.

Table 3. Wavelength and fluorescence intensity of excitation/emitting lights at fluorescence peaks for the water extractable organic matter in black soil after different years of reclamation

\begin{tabular}{|c|c|c|c|c|c|c|c|c|c|c|c|}
\hline \multirow{2}{*}{$\begin{array}{c}\text { Depth } \\
\text { (cm) }\end{array}$} & \multirow[b]{2}{*}{ Years } & \multicolumn{2}{|c|}{1} & \multicolumn{2}{|c|}{ II } & \multicolumn{2}{|c|}{ III } & \multicolumn{2}{|c|}{ IV } & \multicolumn{2}{|c|}{ V } \\
\hline & & $\begin{array}{c}\mathbf{E x} / \mathbf{E m} \\
(\mathbf{n m})\end{array}$ & $\mathbf{F}$ & $\begin{array}{c}\mathbf{E x} / \mathbf{E m} \\
(\mathbf{n m})\end{array}$ & $\mathbf{F}$ & $\begin{array}{c}\mathbf{E x} / \mathbf{E m} \\
(\mathbf{n m})\end{array}$ & $\mathbf{F}$ & $\begin{array}{c}\mathbf{E x} / \mathbf{E m} \\
(\mathbf{n m})\end{array}$ & $\mathbf{F}$ & $\begin{array}{c}\mathbf{E x} / \mathbf{E m} \\
(\mathbf{n m})\end{array}$ & $\mathbf{F}$ \\
\hline \multirow{5}{*}{$0-20$} & 0 & $225 / 330$ & 251.4 & $230 / 380$ & 530.4 & $235 / 440$ & 1043 & $250 / 380$ & 430.8 & $250 / 440$ & 923.7 \\
\hline & 5 & $235 / 330$ & 166.3 & $240 / 380$ & 480.4 & $245 / 447$ & 1011 & $250 / 380$ & 474.1 & $250 / 448$ & 978.1 \\
\hline & 20 & $230 / 330$ & 186.6 & $235 / 380$ & 498.6 & $240 / 440$ & 1048 & $250 / 380$ & 437.5 & $250 / 442$ & 950.3 \\
\hline & 50 & $235 / 330$ & 122.3 & $240 / 380$ & 486.2 & $245 / 445$ & 1025 & $250 / 380$ & 438 & $250 / 443$ & 962.3 \\
\hline & 100 & $235 / 330$ & 97.8 & $245 / 380$ & 579.3 & $245 / 442$ & 1302 & $250 / 380$ & 533.2 & $250 / 444$ & 1172 \\
\hline \multirow{5}{*}{$20-40$} & 0 & $225 / 330$ & 277.7 & $230 / 360$ & 376.5 & $235 / 414$ & 389.2 & $310 / 315$ & 1962 & $310 / 315$ & 1962 \\
\hline & 5 & $230 / 330$ & 141.3 & $235 / 380$ & 395.3 & $240 / 444$ & 823.1 & $250 / 380$ & 327.9 & $250 / 440$ & 716 \\
\hline & 20 & $225 / 330$ & 229 & $235 / 380$ & 460 & $235 / 440$ & 927.2 & $250 / 380$ & 357 & $250 / 444$ & 774.4 \\
\hline & 50 & $235 / 330$ & 137.8 & $240 / 380$ & 527.5 & $245 / 441$ & 1150 & $250 / 380$ & 490.6 & $250 / 449$ & 1031 \\
\hline & 100 & $230 / 330$ & 109.8 & $240 / 380$ & 490.3 & $240 / 440$ & 1089 & $250 / 380$ & 435.1 & $250 / 445$ & 933.2 \\
\hline
\end{tabular}

Ex/Em: Excitation/emitting lights wavelength; F: Florescence intensity I- tyrosine acid-like protein, IItryptophan acid-like protein, III- fulvic acid-like substances, IV- soluble microbial metabolites acid-like substances, V- humic acid-like substances

As indicated in Table 3, for the topsoil of 0-20 $\mathrm{cm}$ underground, the fluorescence intensity decreases with the reclamation, which suggests less tyrosine acid-like protein in the soil. But the increase of the area IV and the obvious increase in the areas III and $\mathrm{V}$ of the fluorescence intensity illustrate the rising contents of fulvic-acid, humic-acid and soluble microbial metabolites acid-like substances, respectively. Their increase can be attributed to the growth of content and activity of microorganisms in the soil promoting the transformation into humic humus. And the unclear changes in the area II indicate the nearly stable content of tryptophan acid-like protein regardless of the reclamation.

In this work, excitation and emitting lights of all fluorescence areas have shown red shift regardless of the reclamation years, which is different with the results from Fu et al. (2004). But a same conclusion of the two researches is that the increase of humic acid concentration results in the red shift of fluorescence peaks. The above distinction can be explained by the microorganism decomposition of plant residues, which is suggested the reason for the proliferation of protein-like substances. Therefore, the analysis of the structure and composition of WEOM in soil with the three-dimensional fluorescence spectrum technology in our research shall be an important theoretical basis for the future researches on micro-ecology of soil.

\section{Conclusions}

Mainly distributed in the provinces of Jilin and Heilongjiang, the northeast black soil region is an important grain production basis. However, the irrational cultivation 
method made the black soil eroded heavily and the water and soil loss increased. Up to now, the area of water and soil loss has accounted for $37.9 \%$ of the whole area. That is why the sustainable utilization of black soil and the interaction between the black soil and environment have been raised to the hot topics of researches, especially the researches about the organic matters in black soil.

In this test, 3D fluorescence spectroscopy was used to study the content, composition and structure of soil water-soluble organic matter in black soils with different reclamation years. The following conclusions: (1) the WEOM in soil has an obvious reduction with the transformation of natural soil into farmland soil, and the reduction is shown increasingly clear with reclamation; (2) the fulvic-acid organic matters have large increases in the molecule, aromaticity, and degree of polycondensation with reclamation; (3) the microorganisms in soil can conduct stronger metabolic activities after the reclamation starts, which utilize the tyrosine acid-like and tryptophan acid-like proteins, and convert more organic matters in soil to fulvic-acid organic matters; (4) the wavelength of emitting lights at the fluorescence peak for the humic-acid organic matters lengthens with reclamation, suggesting the increased molecule, aromaticity and degree of polycondensation. But the tyrosine acid-like, tryptophan acid-like proteins and soluble microbial metabolites acid-like substances keep basically stable contents, which indicates few effects of reclamation on their molecules and aromaticity. In the future, fluorescence spectroscopy, mathematical models, metrology chemistry and other methods should be combined to analyze the characteristics of different source components of DOM, as well as the effects of plant species and crop roots on DOM. The relationship between DOM characteristic substances and fluorescence intensity should be established, so that fluorescence quantization of characteristic substances will be carried out.

Acknowledgements. This work was supported by the National key R\&D project sub-project (2017YFD0300405--4), Natural Science Foundation of Jilin Province, China (20170101077JC), Outstanding Young Talents Fund Project of Jilin Provincial Department of Science and Technology in 2019 (20190103109JH).

\section{REFERENCES}

[1] Chantigny, M. H. (2003): Dissolved and water-extractable organic matter in soils: A review on the influence land use and management practices. - Geoderma 113: 357-380.

[2] Chen, M., Lee, J. H, Hur, J. (2015): Effects of sampling methods on the quantity and quality of dissolved organic matter in sediment pore waters as revealed by absorption and fluorescence spectroscopy. - Environment Science Pollut. Res 22: 14841-14851.

[3] Christ, M. J, David, M. B. (1996): Dynamics of extractable organic carbon in Spodosol forest floors. - Soil Biology and Biochemistry 28: 1171-1179.

[4] Fu, P. Q, Liu, C. Q, Yin, Z. Y. (2004): Characterization of humic acid by threedimensional excitation emission matrix fluorescence spectroscopy. - Geochimica 33(3): 301-308.

[5] Graham, A. M, Aiken, G. R, Gilmour, C. C. (2012): Dissolved organic matter enhances microbial mercury methylation under sulfidic conditions. - Environmental Science and Technology 46(5): 2715-2723.

[6] Hassouna, D. L, Massiani, C. Dudal, Y. (2010): Changes in water extractable organic matter (WEOM) in a calcareous soil under field conditions with time and soil depth. Geoderma 155: 75-85. 
[7] Jones, D. L, Willett, V. B. (2006): Experimental evaluation of methods to quantify dissolved organic nitrogen (DON) and dissolved organic carbon (DOC) in soil. - Soil Biology \& Biochemistry 38: 991-999.

[8] Landgraf, D., Leinweber, P., Makeschin, F. (2006): Cold and hot-water-extractable organic matter as indicators of litter decomposition in forest soils. - Journal of Plant Nutrition and Soil Science 169: 76-82.

[9] Li, M. T, Zhao, L. P, Zhang, J. J. (2013): Effect of temperature, pH and salt on fluorescent quality of water extractable organic matter in black soil. - Journal of Integrative Agriculture 12(7): 1251-1257.

[10] Liang, L., Luo, L., Zhang, S. Z. (2011): Adsorption and desorption of humic and fulvic acids on $\mathrm{SiO} 2$ particles at nano- and microscales. - Colloid Surf, A-Physicochem 384: 126-130.

[11] Liang, Q., Chen, H. Q, Gong, Y. S. (2012): 15 years of manure and inorganic fertilizers on soil organic carbon fractions in a wheat-maize system in the north China plain. Nutrient Cycling in Agroecosystems 92: 21-33.

[12] McGill, W. B, Hunt, H. W, Woodmansee, R. G. (1981): Phoenix a model of the dynamics of carbon and nitrogen in grassland. - Ecol Bull 33: 49-53.

[13] Provenzano, M. R, Dorazio, V., Jerzykiewicz, M., Senesi, N. (2004): Fluorescence behaviour of $\mathrm{Zn}$ and Ni complexes of humic acids from different sources. - Chemosphere 55: 885-892.

[14] Shi, R. H., Bao, S. D. (1908): Soil and Agricultural Chemistry Analysis. - Agricultural Publishing House, Beijing.

[15] Wang, Y. T, Shi, H., Liu, X. F. (2016): Spectrofluorometric characterization of soil dissolved organic matter under different vegetation in Loess Hilly Region. - Journal of Plant Nutrition and Fertilizer 22(1): 171-179.

[16] Weishaar, J., Aiken, G., Bergamaschi, B. (2003): Evaluation of specific ultraviolet absorbance as an indicator of the chemical composition and reactivity of dissolved organic carbon. - Environmental Science \&Technology 37: 4702-4708. 